\section{UVOĐENJE OBITELJSKE MEDIJACIJE U SUSTAV SOCIJALNE SKRBI - PERSPEKTIVA STRUČNJAKA}

\section{SAŽETAK}

Jedna od pretpostavki uvođenja obiteljske medijacije u sustav socijalne skrbi jest i poznavanje dosadašnjih iskustava u provedbi postupka posredovanja pri razvodu braka i mišljenja stručnjaka centara za socijalnu skrb o obiteljskoj medijaciji. Cilj je ovog rada prikazati obilježja postojećeg sustava kako bi se unaprijedilo zajedničko razumijevanje i razvoj obiteljske medijacije. U istraživanju je korišten kvalitativni pristup te su podaci prikupljani na temelju rasprave u dvije fokusne grupe. U navedenim grupama sudjelovalo je trinaest stručnjaka (psiholozi i socijalni radnici), a kao metoda obrade podataka korištena je tematska analiza. Dobiveni rezultati ukazuju na poznavanje osnovih pojmova, ali $i$ stručnjačku zbunjenost spram medijacijskog procesa, posebice u odnosu s drugim profesionalnim postupcima te kada je u pitanju svrha obiteljske medijacije. Ishode medijacije opisuju kroz smanjene konflikte, bolju komunikaciju, stečene uvide i postignute dogovore. Nadalje, temeljem dosadašnjeg iskustva, stručnjaci smatraju da
Stručni članak

Primljeno: prosinac, 2013.

Prihvaćeno: travanj, 2014.

UDK $364.62: 364.46$

DOI 10.3935/ljsr.v21i1.13

Marija Breber ${ }^{1}$

Udruga "Mine alternativni izvori donacija", Zagreb

Branka Sladović Franz ${ }^{2}$

Studijski centar socijalnog rada

Pravni fakultet

Sveučilište u Zagrebu

Ključne riječi:

obiteljska medijacija, posredovanje pri razvodu braka, perspektiva pomažućih stručnjaka.

'Marija Breber, socijalna radnica, e-mail: marijabreber@gmail.com

2 Prof.dr.sc. Branka Sladović Franz, socijalna radnica,

e-mail:branka.sladovic@pravo.hr 
osim kod posredovanja pri razvodu braka, medijaciju primjenjuju i kod sukoba nakon razvoda i između roditelja i djece te opisuju brojne prepreke s kojima se susreću od onih tehničke i organizacijske prirode do onih vezanih uz obilježja korisnika i samih stručnjaka. U zaključku su komentirane dobivene spoznaje pod vidom pojašnjavanja utvrđenih slabih točaka kao temeljenog preduvjeta za postizanje usklađenog poimanja obiteljske medijacije te kao prilog pripremi budućih zakonskih i organizacijskih rješenja.

\section{UVOD}

Obiteljska medijacija podrazumijeva strukturirani proces rješavanja sukoba i spornih pitanja između članova obitelji uz pomoć treće osobe - obiteljskog medijatora u svrhu postizanja zajedničkog sporazuma. Prednosti njene primjene su višestruke, prije svega za članove obitelji koji samostalno donose rješenja za dobrobit cijele obitelj, ali istovremeno uče učinkovitije komunicirati i pregovarati kako bi se osnažili za kvalitetnije održavanje budućih obiteljskih odnosa, neovisno o promjenama i reorganizaciji obiteljskog života. Naime, suvremeni pristup sukobima polazi od spoznaje da je sukob neizbježan dio života, a prije svega dio svake promjene te može biti koristan i pridonijeti razvoju kvalitetnijih odnosa. Sukob je pozitivan i dobar kada sprečava stagnaciju, potiče promjene i brže pronalaženje rješenja problema (Ajduković i Sladović Franz, 2003.). Prema tome, da bi se sukob konstruktivno riješio, potrebno je koristiti različite pregovaračke i komunikacijske vještine te u slučaju nemogućnosti samostalnog rješavanja nastalog nesporazuma moguće je pomoć tražiti od treće neutralne strane. Upravo medijacija kroz svoju strukturu i pravila rada može osigurati međusobno poštovanje, jednakost i pravednost te olakšati komunikaciju između sukobljenih strana (Sladović Franz, 2010.). Medijacija se kao profesionalna vještina počela upotrebljavati u području prava u vidu alternativnih načina rješavanja sporova pri sudu, a prije svega u situacijama razvoda braka koje pripadaju širem području obiteljske medijacije, a kasnije i u drugim područjima (Milne, Folberg i Salem, 2004.). Obiteljska medijacija, osim s pravnom strukom, višestruko je povezana sa socijalnim radom koji se u svim svojim segmentima susreće sa sukobima kao izvorima ali i posljedicama brojnih psihosocijalnih problema. Također, zajednički socijalnom radu i obiteljskoj medijaciji su pravo na samoodređenje i teorijski koncepti i vještine, a Kruk (1997.) naglašava kako je jedinstveni cilj u oba područja osnaživanje korisnika kako bi samostalno riješili ili ublažili postojeće probleme ili nesuglasice.

\section{2 članci}


Razlike u postupcima rješavanja sukoba vezane su u prvom redu uz količinu kontrole koju nad procesom i ishodom imaju sukobljene strane (Sladović Franz, 2010.). Postoji gruba podjela rješavanja sukoba u smjeru suđenja, arbitraže i alternativnog rješavanja spora (Uzelac, 2004.). U posljednje se vrijeme, štoviše, govori o adekvatnom rješavanju sporova, kako bi se naglasilo pravo na izbor načina rješavanja sukoba te da odabir koji je način prikladniji i njegova primjena ovise o sadržaju spora, obilježjima i mogućnostima stranaka i njihovog odnosa (Parkinson, 2011.). Pojmovi mirenje i medijacija sve se više »(...) upotrebljavaju u općim raspravama i međunarodnim dokumentima kao sinonimi« te »(...) danas Ujedinjeni narodi u svojim dokumentima koriste izraz mirenje (koncilijacija), a Vijeće Europe i Europska unija izraz posredovanje (medijacija)« (Uzelac, 2004.: 7). Upravo je trend poticanja alternativnog, odnosno mirnog rješavanja sporova u Hrvatskoj intenziviran početkom dvadesetprvog stoljeća i to mirenje u trgovačkim i građanskim sporovima, odnosno sudska i izvansudska medijacija, mirno rješavanje sporova u kojima je stranka Republika Hrvatska, mirenje u individualnim i kolektivnim radnim sporovima, mirenje u potrošačkim sporovima i posredovanje u obiteljskim imovinskim i statusnim sporovima (Uzelac i sur., 2010.). Posljednji navedeni oblik mirnog rješavanja spora najstariji je i ima najdulju tradiciju. Do sada je isključivo bio vezan uz posredovanje pri razvodu braka, a danas se širi njegova primjena na obiteljske sukobe općenito.

Termini spor i sukob nemaju jednako značenje iako se često tako koriste. Spor bi se trebao koristiti u kontekstu provedbe pravnog postupka, dok svaki tip nesuglasica i sukoba ne mora prerasti u spor već se može riješiti izvansudskim postupcima, bilo samostalno ili uz pomoć treće osobe. No, valja naglasiti da se obiteljska medijacija može koristiti i za rješavanje obiteljskih sporova ako se radi o konkretnim spornim pitanjima (koja mogu biti predmet sudskog postupka), ali i za rješavanje sukoba koji su povezani s osobnim pitanjima ili obiteljskim odnosima.

Opravdanost i važnost primjene obiteljske medijacije proizlazi iz višestrukih prednosti (Sladović Franz, 2010.). Kao prvo, ona omogućuje da odluke donose osobe koje s njima trebaju živjeti, samostalno i odgovorno, čime se ujedno povećava vjerojatnost provedbe sporazuma. Također, taj isti sporazum uvijek se može modificirati ako se za to ukaže potreba. Medijacija omogućuje sagledavanje cjelokupnih potreba sudionika sukoba, usmjerena je na budućnost i konkretne interese i potrebe svih članova obitelji te istovremeno uči sudionike sukoba kako pregovarati i dogovarati optimalna rješenja na dobrobit cijele obitelji, a prije svega djece uz zadržavanje digniteta i kontrole nad obiteljskom situacijom. Kako se danas razvod braka ne smatra više krajem obiteljskog života (osobito iz perspektive djeteta) već reorganizacijom obitelji, tako navedene prednosti u tom kontekstu imaju preventivni učinak u svezi negativnih posljedica razvoda na individualnoj razini, ali i zau- 
stavljanja sudskih sporova (Parkinson, 2011.). Irving i Benjamin (1995.), opisujući brojna istraživanja rađena u ovom području, naglašavaju kako je vrijednost medijacije upravo u sporazumima koji su za razliku od sudskih odluka u većoj mjeri sveobuhvatni, pravedniji i rađeni u smjeru podjele roditeljskih obaveza.

Teorijski koncepti koji utječu na razvoj medijacije su višestruki: teorija sukoba, teorija pregovaranja, sistemska teorija, teorija komunikacije, konstruktivistička teorija. Općenito gledano, utjecaj imaju teorije koje proizlaze iz socio-psihološke tradicije kao što je npr. konstruktivistička teorija koja »(...) govori o vezi između razine kognitivne kompetentnosti i komunikacije.« (Žižak, 2012.: 68). U kontekstu medijacije, medijator bi trebao imati odgovarajuću, višu razinu kognitivne kompleksnosti koja mu omogućuje vješto vođenje i usmjeravanje čitavog procesa. U smislu vještina, posebno su važni upotreba neutralnog govora, metafora, postavljanje pitanja, reflektiranje, preoblikovanje, parcijalizacija, normaliziranje, poticanje uzajamnosti, usmjeravanje na budućnost, usmjeravanje na zadatak (Sladović Franz, 2005.). Navedene vještine, prema Sprafkin, Gershaw i Goldstein (1993., prema Ajduković, 2012.), pripadaju u složene komunikacijske vještine. Iznimno važan korpus kompetencija predstavljaju znanja iz područja prava te je ono također sastavni dio edukacije ili ukoliko njega nema, nužna je komedijacija s pravnikom ili upućivanje sudionika medijacije na traženje pravnog savjeta i pomoći pri sastavljanju sporazuma o imovinskim pitanjima.

Zanimljivo navodi Parkinson (2011.: 3) - »Više disciplina (pravo, psihologija, socijalni rad) se bore za 'skrbništvo' nad medijacijom, kao i roditelji u razvodu« jer su obiteljski medijatori najčešće izvorno psiholozi, socijalni radnici i pravnici te njihovo formalno obrazovanje, okruženje i uvjeti određuju pristup medijaciji. Pravnici su skloniji medijacijama koje su visoko strukturirane i usmjerene na sporazum, dok stručnjaci iz pomažućih profesija naginju terapijskom i transformativnom pristupu medijaciji. Kruk (1997.) je tako, primjerice, razvio terapeutsko-intervencionistički pristup isključivo za socijalne radnike i druge stručnjake humanističke profesije koji rade $s$ razvedenim roditeljima na roditeljskim planovima u cilju zaštite dječjih prava. Edukativni standardi te kriteriji certificiranja i nužnost supervizije kao preduvjeti kvalitete rada obiteljskih medijatora razlikuju se kako unutar neke profesije tako i među državama (Očko, 2011.).

U Hrvatskoj je do sada praksa pružanja obiteljske medijacije bila vezana najčešće za područje posredovanja prilikom razvoda braka (ObZ, NN, 116/03, 17/0 4, 136/04, 107/07, 57/11, 61/11, 25/13) te nije zahvaćala ostale moguće sadržaje obiteljske medijacije iako je naglašena u Preporuci Vijeća Europe br.R (98) $1^{3}$ upra-

\footnotetext{
3 Mrežna stranica Vijeća Europe: $h t t p s: / / w c d . c o e . i n t /$ ViewDoc.jsp?id=461347\&Site $=$ COE\&BackColorlnternet $=D$ BDCF2\&BackColorlntranet=FDC864\&BackColorLogged $=$ FDC864.
}

\section{4 članci}


vo primjena obiteljskog posredovanja u svim sporovima među članovima obitelji (Alinčić, 1999.; Korać 2005.). Tijekom 2011. i 2012. godine doneseni su Zakon o socijalnoj skrbi (NN, 57/11; NN, 33/12) sukladno kojem su se mogle pružati usluge obiteljske medijacije koja je bila definirana kao »socijalna usluga koja se pruža u specifičnom postupku rješavanja obiteljskih sukoba uz pomoć educiranog medijatora čiji je cilj postizanje sporazuma o neriješenim sporovima i sukobima za dobrobit cijele obitelji« (NN, 57/11, članak 99., točka 1.). Drugim riječima, proširilo se područje primjene obiteljske medijacije koja je do tada bila sadržajno predviđena samo u gore spomenutim situacijama razvoda braka. Upravo se time nastojalo da obiteljska medijacija kao socijalna usluga ima preventivni karakter pomažući obiteljima u dobrovoljnom rješavanju sukoba i provedbi sporazuma i neovisno o tome je li nužno ili nije sporazum dostaviti sudu radi potvrde ovršnosti, odnosno je li taj postupak ujedno i način adekvatnog rješavanja sporova iz perspektive sustava pravosudja. Novi Zakon o socijalnoj skrbi (NN, 157/13) ponovno u popisu socijalnih usluga nema navedenu obiteljsku medijaciju čime se gubi preventivni karakter i poticanje pravovremenog korištenja pregovaranja i medijacije kao metoda pomaganja obiteljima u krizi s obzirom da su sukobljavajući obiteljski odnosi često ishodište ili posljedica drugih socijalnih rizika. Obiteljska se medijacija planira regulirati budućim Obiteljskim zakonom (Prijedlog obiteljskog zakona 2013.) čime je otvorena mogućnost rješavanja spornih pitanja u kontekstu razvoda ili prekida izvanbračne zajednice, roditeljske skrbi i ostvarivanja osobnih odnosa te imovinskih i svih drugih pitanja među članovima obitelji. Valja napomenuti da su se određena obiteljska pitanja mogla rješavati i prije opisanih promjena s obzirom da su nadležnost i postupak mirenja definirani Zakonom o parničnom postupku, Zakonom o trgovačkim sudovima i Zakonom o mirenju i s obzirom da ni jedan od navedenih propisa ne isključuje mogućnost mirenja za bilo koji tip spora (Uzelac i sur., 2010.). Sukladno tome, mirenjem odnosno medijacijom mogu se rješavati svi sporovi gdje se govori o pravima kojima stranke mogu slobodno raspolagati (Sladović Franz, 2005.; Uzelac i sur., 2010.). No, ovdje se kao relevantno pitanje postavlja roditeljsko raspolaganje pravima djece u obiteljskim sporovima, s obzirom da iskustvo pokazuje kako ponekad u tim situacijama interesi djece dolaze u sukob s interesima samih roditelja. Roditelji vrlo često manipuliraju djetetovim pravima što potvrđuje i istraživanje Ureda pravobraniteljice za djecu (Filipović i Osmak-Franjić, 2010.) koje ukazuje da su stručni radnici centara za socijalnu skrb procijenili da od ukupnog broja obiteljskih intervencija godišnje u 30\% slučajeva dolazi do manipulacije djetetovim pravom na susrete i druženja s drugim roditeljem.

Europska unija nije sklona detaljnom reguliranju obiteljske medijacije naglašavajući da bi ona trebala biti neformalna i fleksibilna. Ona se ne bavi obiteljskom medijacijom kao zasebnom problematikom, već općenito govori o važnosti osigu- 
ranja alternativnih načina rješavanja sporova u smislu ljudskog prava na pristup pravdi (Majstorović, 2007.). Kroz razne dokumente nastoji promicati primjenu alternativnih oblika rješavanja sporova što se ujedno odnosi i na obiteljske sporove, kao npr. Zelena knjiga o alternativnom rješavanju sporova u građanskom i trgovačkom pravu ${ }^{4}$ (2003.), Rezolucija Europskog parlamenta (2004.), Europski kodeks ponašanja posredovatelja, prijedlog Direktive Europskog parlamenta i Vijeća o određenim aspektima posredovanja u građanskim i trgovačkim predmetima (Majstorović, 2007.) koju je i usvojila 2008. godine. Europska komisija uspjela je potaknuti uspješnu raspravu koja je rezultirala različitim prijedlozima i zaključcima. Između ostalog, predloženo je uvođenje obveznog prisustvovanja jednom susretu vođenom alternativnom metodom koji bi trebao biti besplatan i ne stvarati obavezu daljnjeg sudjelovanja u postupku. Naime, kako je dobrovoljnost sudjelovanja temeljno načelo obiteljske medijacije, prvi susret s obiteljskim medijatorom (koji se planira u prijedlogu novog Obiteljskog zakona ${ }^{5}$ ) sadržajno odgovara tzv. predmedijacijskom postupku čija je svrha dvojaka: s jedne strane treba pojasniti prednosti medijacije, postupak i uloge sudionika kako bi oni donijeli informiranu odluku je li medijacija za njih prikladan način rješavanja sporova i sukoba, a s druge strane za obiteljskog je medijatora to prilika procijeniti jesu li ostvarene pretpostavke za ulazak u obiteljsku medijaciju - spremnost na suradnju, kompetentnost i ravnoteža moći (Parkinson, 2011.). Dobivanje prikladnih informacija i pažljiva procjena povećavaju vjerojatnost da se medijacija održi kada su okolnosti povoljne i vjerojatnost uspješnog dogovora i postizanja sporazuma najveće ili odabere postupak koji je prikladniji za zaštitu prava i interesa. U obiteljsku medijaciju mogu ući samo osobe koje su zaista spremne na suradnju i žele se dogovoriti, osobe koje su kompetentne i sposobne postići i provoditi sporazum te koje su u dovoljnoj ravnoteži moći koja osigurava ravnopravne pregovore. Tako npr. sudionicima visokokonfliktnih razvoda obiteljska medijacija najčešće nije preporučljiva jer nespremnost na suradnju (već na sukobljavanje) te neravnoteža moći (obično uz neke elemente barem verbalnog i psihološkog nasilja) ukazuju da nisu ostvarene pretpostavke. Bez postojanja pretpostavki obiteljska će medijacija vjerojatno biti neuspješna, a može biti i opasna po sigurnost i prava sudionika te se u određenim situacijama ne preporuča provoditi ju. Ne trebaju ulaziti u medijaciju one osobe koje nisu u mogućnosti (npr. zbog dobi, kognitivnih ili psihičkih oštećenja, statusa žrtve, itd.) na prikladan način i u svoju korist štititi svoje interese, već će to u njihovo ime vjerojatno kvalitetnije učiniti zastupnik ili odvjetnik. Valja naglasiti da se pod određenim okolnostima može provesti obiteljska medijacija i uz prethodno postojanje

\footnotetext{
4 Na mrežnoj stranici: http:// eurlex.europa.eu/LexUriServ/site/en/com/2002/com20020 196en01.pdf. 5 Preuzeto shttp://www.mspm.hr.
}

\section{6 članci}


određenih manjih ili incidentnih nasilnih ponašanja ili onih koji su se dogodili u prošlosti, ukoliko medijator procijeni da to ne izaziva neravnotežu moći (niti je u pitanju dinamika nasilja u obitelji), a sudionici žele sudjelovati. Obiteljski medijatori su kao dio svog etičkog postupanja dužni ne ući u postupak ili prekinuti obiteljsku medijaciju kada uvide da nisu ispunjene pretpostavke.

Potaknuti suvremenim europskim putovima razvoja obiteljske medijacije, domaćim početnim koracima u zakonskom, obrazovnom i organizacijskom smislu, anticipiranom promjenom profesionalnih zadataka te sobzirom na to da se do sada postupak posredovanja provodio pretežito u centrima za socijalnu skrb u području razvoda braka, smatramo da perspektiva iskusnih stručnjaka predstavlja polazišnu točku na kojoj valja graditi uvođenje, ali i daljnje razvijanje obiteljske medijacije unutar sustava socijalne skrbi te će u ovom radu biti prikazan dio šireg istraživanja koje je provela Breber 2012. godine.

\section{CILJ I METODOLOGIJA ISTRAŽIVANJA}

Kako bi se utvrdila perspektiva stručnjaka centara za socijalnu skrb o obiteljskoj medijaciji te o dosadašnjem iskustvu, postavljena su, između ostalih, i slijedeća istraživačka pitanja:

a) Kako stručnjaci opisuju i određuju obiteljsku medijaciju kao profesionalni postupak?

b) Koja su dosadašnja iskustva stručnjaka u provedbi postupka posredovanja prilikom razvoda braka u centrima za socijalnu skrb i medijacije u drugim obiteljskim pitanjima?

U istraživanju je korišten kvalitativni pristup s obzirom da se željelo dobiti dublji uvid i razumijevanje istraživačkih problema, a temeljem proučavanja iskustva i doživljaja sudionika (Milas, 2005.). U ovom kontekstu važni su doživljaji stručnjaka zaposlenih u centrima za socijalnu skrb s obzirom na njihovo jedinstveno iskustvo provedbe postupka. Istraživanja provedena u području obiteljske medijacije relativno su skromna, stoga se ovim istraživanjem željela dobiti šira slika predmeta istraživanja, odnosno rezultati koji će nam pružiti bolje razumijevanje obiteljske medijacije iz stručnjačke pozicije. Istraživanje je opisno, a proces zaključivanja deduktivan s obzirom da je kao metoda obrade podataka korištena tematska analiza. Važnost je pridavana značenju i razumijevanju riječi sudionika (Tkalac Verčič, Sinčić Ćorić i Pološki Vokić, 2010.; Koller Trbović i Žižak, 2008.), a zaključci izvedeni temeljem dobivenih podataka i teorijskih spoznaja. Podaci o mišljenju stručnjaka 
prikupljani su na temelju rasprave u fokusnim grupama kako bi se omogućilo sudionicima iznošenje svojih mišljenja temeljenih na stvarnom iskustvu u ulozi stručnjaka, konkretno socijalnih radnika i psihologa, koji provode posredovanje prilikom razvoda braka u centrima za socijalnu skrb. Sukladno navedenom, za potrebe istraživanja, korišten je unaprijed pripremljen predložak za razgovor sastavljen od otvorenih pitanja koja navode na razgovor i nisu opterećena mogućim odgovorima.

Sudionici istraživanja bili su trinaest stručnjaka zaposlenih u centrima za socijalnu skrb na području Krapinsko-zagorske županije i Grada Zagreba. Uzorak je bio heterogen po dobi, spolu, zvanju i dužini radnog staža. lako zakonska regulativa, u okviru razvoda braka pretpostavlja i prisutnost pravnika čiji zadatak je upoznati partnere s pravnim posljedicama razvoda, oni nisu bili uključeni u ovo istraživanje jer najčešće u praksi ne sudjeluju u postupku posredovanja. Kriteriji za izbor sudionika uključivali su motivaciju za sudjelovanje u fokusnoj grupi, iskustvo rada u centru za socijalnu skrb na postupku posredovanja te zvanje u smislu da je istraživanje uključivalo isključivo socijalne radnike i psihologe. Pozvani su da sudjeluju u istraživanju tijekom stručne edukacije na temu sveobuhvatnog obiteljskog procjenjivanja i individualnog planiranja u zaštiti djece. Zbog prigodnosti uzorka i konteksta prikupljanja podataka, kao kriterij uključivanja u istraživanje nije bila duljina radnog staža koji je pojedini sudionik proveo radeći na području posredovanja prilikom razvoda braka obiteljske medijacije.

U fokusnim grupama sudjelovalo je 12 ženskih i 1 muška osoba u dobi od 28 do 60 godina. Prosjek godina svih sudionika je 39 godina. Većina je socijalnih radnika (njih 9) i 4 psihologa. Važno je napomenuti da su se neki sudionici i dodatno obrazovali tako da je jedan sudionik završio specijalizaciju iz supervizije, a jedan je magistrirao dječju i adolescentnu psihijatriju. Također, tri sudionika su trenutno na specijalizaciji. Svi sudionici su prošli različite dodatne edukacije u obliku neformalnog obrazovanja, kao što je to edukacija iz psihoterapije (sistemske, transakcijske, realitetne, kognitivno-bihevioralne), edukacije vezane uz nasilje u obitelji, probleme ovisnosti, komunikacijske treninge i drugo. Radno iskustvo sudionika na poslovima posredovanja kreće se od 4,5 mjeseci do 30 godina, te je prosjek godina iskustva na poslovima posredovanja 4,59 godina. Iskustvo sudionika na drugim poslovima kreće se od 8 mjeseci do 37 godina, odnosno prosječno 9,25 godina. Svi sudionici imaju iskustvo rada u centru za socijalnu skrb, najčešće na poslovima općeg socijalnog rada, odjelu zaštite djece i mladeži, kao i s poremećajima u ponašanju.

Prije samog istraživanja, a u okviru edukacija održanih u Zagrebu i Krapini na temu sveobuhvatnog obiteljskog procjenjivanja i individualnog planiranja u zaštiti djece, održani su sastanci sa stručnjacima u svrhu upoznavanja s ciljevima

\section{8 članci}


M. Breber , B. Sladović Franz: Uvođenje obiteljske medijacije u sustav socijalne skrbi...

istraživanja i definiranja suradnje potrebne za formiranje fokusnih grupa. Nakon dobivanja usmene suglasnosti sa sudionicima je dogovoreno vrijeme i mjesto održavanja fokusnih grupa. Prije početka razgovora u fokusnim grupama sudionici su informirani o osiguranju povjerljivosti podataka, zaštititi identiteta te je još jednom istaknuto u koju svrhu će se koristiti rezultati istraživanja kao i mogućnost pružanja povratne informacije o dobivenim rezultatima. Prva fokusna grupa održana je u prostoru Centra za socijalnu skrb Krapina u Krapini, a druga u prostoru nevladine organizacije Udruženje Djeca prva u Zagrebu. Svaka grupa imala je jednog voditelja i jednog suvoditelja. Tijekom rasprave suvoditelj je vodio bilješke te u određenim trenucima tražio detaljnije opise od sudionika odgovarajućim potpitanjima. Rasprave u fokusnim grupama bile su snimane diktafonom temeljem dozvole samih sudionika, a u svrhu lakšeg bilježenja i obrade podataka. Grupna rasprava u prvoj fokusnoj grupi je trajala 120 minuta, a u drugoj 90 minuta.

Prikupljeni podaci obrađivani su kvalitativnom analizom pri čemu je korišten postupak tematske analize (eng. framework analysis) koji obuhvaća pet faza: proces upoznavanja s građom, postavljanje tematskog okvira, indeksiranje (kodiranje), unošenje u tablice, povezivanje i interpretacija (Ritchie i Spencer, 1994., prema Ajduković i Urbanc, 2010.). Tematska analiza smatra se prikladnom upravo za istraživanja koja imaju specifična pitanja, ograničeno vrijeme provedbe, a teme za koje tražimo odgovore unaprijed su definirane (Srivastava i Thomson, 2009.).

\section{PRIKAZ REZULTATA I RASPRAVA}

\section{Opis i određenje obiteljske medijacije kao profesionalnog postupka iz perspektive stručnjaka}

Prvo istraživačko pitanje bilo je usmjereno na dobivanje informacija kako stručnjaci zaposleni u centrima za socijalnu skrb općenito doživljavaju obiteljsku medijaciju. Dobiveni podaci ukazuju da sudionici istraživanja raspolažu određenim informacijama o obiteljskoj medijaciji temeljem kojih i opisuju svoj doživljaj i stav prema predmetu istraživanja, ali su istovremeno vrlo zbunjeni u razumijevanju obiteljske medijacije, posebice u relaciji s drugim profesionalnim postupcima. Tematsko područje opis i određenje obiteljske medijacije kao profesionalnog postupka (tablica 1.) obuhvaća četiri specifične teme i pripadajuće im kategorije. 
Ljetopis socijalnog rada 2014., 21 (1), 123-152 str.

Tablica 1. Opis i određenje obiteljske medijacije kao profesionalnog postupka

Tematsko područje:

Opis i određenje obiteljske medijacije kao profesionalnog postupka

\begin{tabular}{|c|c|}
\hline Tema & Kategorija \\
\hline \multirow{4}{*}{$\begin{array}{l}\text { Stručnjačka definicija obitelj- } \\
\text { ske medijacije }\end{array}$} & Postojanje sukoba \\
\hline & Strategije rješavanja \\
\hline & Strukturiranost postupka \\
\hline & Proces usmjerava stručnjak-medijator \\
\hline \multirow{3}{*}{ Ciljevi } & Ciljevi za korisnike \\
\hline & Ciljevi za stručnjake \\
\hline & Ciljevi iz zakonske perspektive \\
\hline \multirow{4}{*}{ Ishodi uspješne medijacije } & Smanjeni ili/i prevladani konflikti i nezadovoljstva \\
\hline & Podignuta razina i vještine komunikacije \\
\hline & $\begin{array}{l}\text { Stečeni uvidi i preuzeta odgovornost za vlastita po- } \\
\text { našanja }\end{array}$ \\
\hline & $\begin{array}{l}\text { Postignuti zajednički dogovori s naglaskom na pita- } \\
\text { nja oko djece }\end{array}$ \\
\hline \multirow{4}{*}{ Nejasnoće } & $\begin{array}{l}\text { Ambivalencija prema Zakonu o socijalnoj skrbi (NN, } \\
57 / 11 \text {.) }\end{array}$ \\
\hline & Pojam obiteljske medijacije \\
\hline & Obiteljska medijacija i posredovanje \\
\hline & Obiteljska medijacija i savjetovanje \\
\hline
\end{tabular}

\section{a) Stručnjačka definicija obiteljske medijacije}

Stručnjaci navode da obiteljsku medijaciju karakterizira postojanje sukoba i prisutnost suprotstavljenih strana (»U stvari ja mislim da bi medijaciju trebali raditi kad postoji nekakav sukob, da je to onda posao, imamo sukob, dvije suprotstavljene strane." (1.5.)) pri čemu se sukobi rješavaju primjenom određenih strategija kao što su pregovaranje, arbitraža ili pak kompromis (»Netko nešto da, netko će od nečeg odustati, ako se žele naći na nekakvoj sredini. Kao da će se pogađati.» (1.3.)). Sve to zahtijeva odgovarajuću strukturiranost postupka koja se odnosi na prolazak 
M. Breber , B. Sladović Franz: Uvođenje obiteljske medijacije u sustav socijalne skrbi...

kroz konkretne faze (»Znači da je medijacija, ja bar imam ideju pod tom riječi, da ima malo strukturirane i zadane korake rada, da bi se nešto zvalo medijacijom, onda bi se to moralo po 1,2,3,4,5 fazama raditi.«(1.5.)), a cijeli proces usmjerava stručnjakmedijator (»Ono što ja doživljavam kao obiteljsku medijaciju da stručna osoba... usmjerava taj razgovor konačnom nekakvom cilju... Znači, uz pomoć stručne osobe jer sami bez toga ne bi mogli i da postignu nekakve dogovore koji će im pomoći u daljnjoj komunikaciji i funkcioniranju.«(2.3.)).

Sukladno prikazanim rezultatima, vidljivo je da stručnjačka definicija u velikoj mjeri odgovara i sadrži temeljne elemente teorijskih definicija, kao što su sukob, pregovaranje, strukturiranost i prisutnost stručnjaka kao treće neutralne strane. Sudionici jednako tako prepoznaju medijaciju kao proces kojem pristupaju osobe koje same nisu mogle riješiti nastali sukob, ali istovremeno ne prepoznaju fokusiranost medijacije na konkretna sporna ptianja.

\section{b) Ciljevi}

Tijekom rasprave, u fokusnim grupama pokazalo se da stručnjaci percipiraju niz ciljeva koji bi se trebali ostvariti tijekom procesa, odnosno ishoda kojima bi medijacija trebala rezultirati. Upravo zbog brojnosti i raznolikosti iznesenih ciljeva isti su razvrstani u tri kategorije: ciljevi za korisnike, ciljevi za stručnjake i ciljevi iz zakonske perspektive.

Kod ciljeva za korisnike stručnjaci navode kako je važno postići iskazivanje interesa i potreba sudionika sukoba, odnosno da korisnici iskoriste priliku koju im medijacija pruža u vidu da jedan drugoga saslušaju i čuju ( »...da oni jedan drugoga bolje čuju o razlozima koje imaju reći zbog čega se ponašanje njihovo manifestira na određeni način, što žele, koje su njihove potrebe.» (1.3.)). Kao središnji cilj medijacijskog procesa percipiraju zaštitu djece oko koje se najčešće i javljaju sukobi kada je u pitanju razvod braka. Naglašavaju kako roditelji tijekom razvoda često koriste svoju djecu kako bi ostvarili vlastite ciljeve te da im je upravo zbog toga potrebna posebna zaštita kako bi bila što manje »oštećena« (»... a to bi onda i ja prihvatila kao jedan od ciljeva, ... da se nađu najbolji mogući ishodi vezani za razvod braka, a konkretno se odnose na djecu, i sve one posljedice, susrete, druženja i povjeravanje."(1.4.) s čime se slaže i (1.2.): »... ali ono što je ipak najvažnije da postignu dogovor oko djece, to nam je najvažnije.«(1.2.)).

Kao krajnji cilj pregovora opisuju postizanje dogovora/rješenja na obostrano zadovoljstvo (»Dok medijacija bi, po meni, krajnji ishod bi bio rješenje nečega." (1.6.); "Ja se slažem da je cilj postizanje dogovora koji je znači za obje strane ono što oni žele." (2.1.)). Istovremeno smatraju važnim da korisnici donesu odluke o budućnosti bra- 
ka (»Koji konačni cilj može biti medijacije? Ili pomirba ili razvod."(1.6.)) što upućuje na potrebu savjetotovanja ili terapijskog razgovora koji bi trebao prethoditi medijaciji, a ne biti njezin sastavni dio.

Nadalje, kao cilj ističu podizanje kvalitete života kroz uspostavljanje pozitivnih i unaprijeđenih odnosa (»...da ostanu i dalje u odnosima koji bi trebali biti ok, koji bi trebali biti pozitivni za jednoga i drugoga, ... gdje će se moći dogovoriti o važnim pitanjima koja proizlaze iz braka, nastavka života."(1.3.)). Smatraju da medijacija treba ostaviti pozitivan trag u njihovom životu i daljnjem održavanju odnosa, a to uključuje i poštovanje dogovora, te skladno roditeljsko funkcioniranje.

Ciljevi za stručnjake podrazumijevaju upoznavanje korisnika s ulogama u odnosu stručnjak - korisnik te s odgovornošću za rješavanje vlastitog problema i konačno motiviranje korisnika za dogovaranje i druge oblike pomoći kao što je bračno savjetovalište (»Cilj mi je prvo da ih upoznam koja je uloga, drugo da oni shvate da samo oni mogu riješiti taj problem, da ih u tom dijelu pokušam motivirati ... da ih pokušam motivirati da krenu u bračno savjetovalište." (2.2.); (»Da li se može raditi na tim problemima ili ne, da li ima motivacije jednog i drugog da se radi..."(1.1.)).

Motiviranost korisnika važan je preduvjet za provedbu medijacije kao i informiranost o ulogama. Isto navodi i Parkinson (2011.) koja smatra da medijator tijekom cijelog procesa mora provjeravati motiviranost i dobrovoljnost sudjelovanja korisnika. Europski kodeks ponašanja posredovatelja ${ }^{6}$ također navodi da je medijator dužan osigurati razumijevanje obilježja medijacije, ulogu medijatora i samih sudionika. Ovdje je vidljivo da stručnjaci ne spominju informiranje korisnika o cijelom procesu iako tijekom daljnje rasprave navode važnost uspostavljanja pravila i definiranja ciljeva kao uvjeta za uspješnu medijaciju. Svakako bi bilo važno da stručnjaci u praksu uvedu procjenu korisnika, ne samo u smislu motivacije, već $i$ isključivanja konflikata okarakteriziranih situacijama i okolnostima koje se ne mogu rješavati medijacijom. Navedenu problematiku u određenoj mjeri prepoznaju i sudionici fokusnih grupa s obzirom da kao cilj spominju i uključivanje partnera u odgovarajući oblik savjetovanja jer su svjesni da se medijacijom ne mogu riješiti ni svi sukobi ni problematični odnosi (već je potrebno dulje savjetovanje ili terapija). Kao specifičan stručnjački cilj prepoznata je i potreba za poučavanjem roditelja kako postići dogovor s adolescentima (»Ja često volim ta nekakva mini posredovanja napraviti između roditelja i djece, ... Većinom zato da pokažem roditeljima da se neke stvari mogu riješiti dogovorno s adolescentima.«(2.7.)).

Ciljevi iz zakonske perspektive se, kao što i sam naslov govori, temelje na zakonskoj regulativi, točnije Obiteljskom zakonu (NN, 116/03.). Sudionici navode kako je primarni cilj zakonodavca očuvanje obiteljske zajednice i prevladavanje

${ }^{6}$ http://ec.europa.eu/civiljustice/adr/adreccodeconducten.pdf, preuzeto 25.10.2011.

\section{2 članci}


bračnih/partnerskih konflikata te u slučaju razvoda braka cilj postaju dogovori oko djece (»...cilj zakonodavca bio je da se pokuša raditi na očuvanju obiteljske zajednice. I onda idemo s time da supružnici prevladaju tu bračnu krizu..." (2.2); "Obiteljski zakon, ili ja to krivo gledam, je tako zamislio. Da se njihov brak održi ili ne. Ako ne, ok, da onda idemo vidjeti što će biti s djetetom i tako dalje.« (2.4.)). Tijekom rasprave uočena je ambivalencija sudionika koji ponekad navode da svrha medijacije nije mirenje partnera, već postizanje optimalnog dogovora, a ponekad ističu važnost prevladavanja partnerskih konflikata i očuvanja bračne zajednice te upućivanja partnera na savjetovanje. Do navedenog je došlo upravo zbog toga što je posredovanje prilikom razvoda braka trebalo uključivati medijaciju, ali i više od toga - edukaciju, pomirenje i stručnu procjenu. Stoga prijedlog novog Obiteljskog zakona donosi razgraničavanje uloge stručnjaka na način da a) prije pokretanja razvoda braka i u drugim situacijama sporova o djeci provode obavezno savjetovanje koje ima primarno edukativnu funkciju, b) obiteljski medijatori provode postupak pomaganja članovima obitelji da donesu sporazumna rješenja i c) ako se ne mogu članovi obitelji dogovoriti sami niti uz pomoć obiteljskog medijatora (ili ako to iz drugih razloga nije moguće), tada je potrebna procjena stručnjaka socijalne skrbi u obliku mišljenja sudu gdje se postupak vodi. Obiteljski medijatori ne mogu sudjelovati u postupku izrade mišljenja sudu zbog načela povjerljivosti, nepristranosti i neutralnosti.

\section{c) Ishodi uspješne medijacije}

Analiza je pokazala da stručnjaci percipiraju obiteljsku medijaciju uspješnom ukoliko se kod korisnika smanje ili/i prevladaju konflikti (»Procjenjujem da je uspješna ako su oni do neke mjere smanjili svoje konflikte, nezadovoljstva i pomirili se s činjenicom raspada braka. (1.5.); »Ako ide u smjeru razvoda da taj razvod bude što je moguće manje nasilan i što je moguće manje konfliktan." (1.5.), s čim se slaže i (1.1.)) i ukoliko korisnici uspiju postići veću razinu i vještine komunikacije (»Uspješna je ukoliko supružnici, ... nauče komunicirati da postignu bar nešto... « (2.1.); »Da se poboljša komunikacija članova obitelji.«(2.4.)). Zanimljivo je da su istraživanja Irvinga i Benjamina (1992., prema Irving i Benjamin, 1995.) o uspjehu i rezultatima medijacije pokazala kako sami korisnici procjenjuju da im je sudjelovanje u medijaciji pomoglo da smanje postojeće konflikte, unaprijede komunikaciju i roditeljske odnose te obveze.

Također, medijacija je uspješna ukoliko su stečeni uvidi i preuzeta odgovornost za vlastita ponašanja pri čemu ako to nije postignuto tijekom posredovanja, potrebno je korisnike potaknuti na druge oblike pomoći (»Kad suprotstavljene stra- 
ne kažu... Odlučili smo prestati to raditi jedan drugome i samima sebi jer smo shvatili, sad imamo uvida u vlastito ponašanje... Dakle, kad shvate i jedan i drugi da time što su radili sebi i drugome da su se povrijedili na razini nekakvog dostojanstva, integriteta... « (1.3.); »...da kroz taj proces ljudi nekako steknu uvid možda u svoje postupke, svoje probleme. Da preuzmu odgovornost za svoje ponašanje." (2.5.); »Uspješna je ukoliko supružnici, iako odluče da će se razvesti, posredovanje kao takvo nije uspjelo, uspiju... i uključiti se u neku vrstu savjetovanja, partnersku terapiju, bilo kakvu.«(2.1.)).

Navedena percepcija stručnjaka upućuje da medijaciju ne doživljavaju kao proces u kojem se riješava samo konkretan, praktičan sukob, već se postiže stjecanje uvida, osnaživanjem u smjeru unapređenja kvalitete odnosa između članova obitelji što može, ali i ne mora, biti sekundarna dobit medijacije. Stoga se može zaključiti naklonost stručnjaka transformativnom modelu medijacije koji dublje ulazi u potrebe i interese pojedinaca te kvalitetu njihova odnosa. Činjenica je da je zakonodavac od stručnjaka u CZSS-ima očekivao rad na stjecanju uvida i prevladavanju bračnih poteškoća s jedne strane te evaluativni pristup, kroz donošenje procjena i stručnog mišljenja, s druge strane. Tako da se u praksi zapravo na neki način koristio tzv. kombinirani model, dok facilitativni, kao temeljni model proizašao iz generičkog socijalnog rada, izostaje iz obje perspektive, kako stručnjaka tako i zakonodavca (Sladović Franz, 2005.).

Nadalje, stručnjaci posebno uspješnom medijacijom smatraju kada su postignuti zajednički dogovori s naglaskom na pitanja oko djece (»Procjenjujem da je uspješna ako se ... uspiju dogovoriti o djeci i o svim drugim aspektima, onda to stvarno smatram uspješnim. «(1.5.); Onda smo vrlo zadovoljni ako uspijemo barem postići to da oni postignu dogovor o toj roditeljskoj skrbi i da je dijetu osigurano učešće oba roditelja u njegovom odrastanju.« (2.2.)). S obzirom da su sudionici kao ključni cilj medijacije naveli zaštitu djece, za očekivati je da uspješnu medijaciju povezuju s postignutim dogovorima oko roditeljske skrbi, a u najboljem interesu djece.

\section{d) Nejasnoće}

Tijekom razgovora u fokusnim grupama bilo je očito da su stručnjaci u velikoj mjeri zbunjeni vezano uz razlikovanje pojmova i postupaka i praktične mogućnosti. Analiza je pokazala ambivalenciju prema tada važećem Zakonu o socijalnoj skrbi (NN, 57/11.). Sudionici fokusnih grupa načelno medijaciju doživljavaju kao dobru ideju, odnosno inicijativu (»Dobra ideja, ali... teško primjenjivo.« (1.1.); »Ja mislim da je dobro da se to kao mogućnost uvede.... mislim da je to kao inicijativa u redu." (1.5.);)Jednostavno nemamo mogućnost u CZSS-u to raditi, ja imam osjećaj iz vlastite perspektive.«(1.3.)). S druge strane, sumnjaju u izvedivost obiteljske medijacije u centrima za socijalnu skrb jer ne vide prostor i vrijeme za njegovu primjenu s ob-

\section{4 članci}


zirom na veliku radnu opterećenost. Nadalje, sudionici imaju poteškoće s razumijevanjem pojma obiteljske medijacije, pri čemu smatraju da je riječ o važnom, »visokom« pojmu, ali istovremeno nedovoljno jasnom. Jedan stručnjak snažno naglašava nerazumijevanje obiteljske medijacije koja mu se čini važna, ali i jednako tako apstraktna. Nikada mu nitko nije pojasnio što i kako bi trebala obiteljska medijacija izgledati (»... iskreno ne znam kako se definira obiteljska medijacija, meni stvarno nije jasno. Ja imam dojam da je to nekakav visoki kao na Olimpu pojam s vašeg faksa, to je moje iskreno mišljenje. O kojem se samo priča kao nečem jako velikom, jako važnom, ali ja od kada radim u centru, nigdje nisam našla što je to, što se s time misli, tko to zna radit, tko će to znati raditi.... pojam koji je kao srž svega, a ja ne znam ništa o tome. ...na obiteljskoj medijaciji nikad bila, nikad čula i ne znam što uopće je. ...mogu pretpostaviti što je, ... ali uglavnom mislim da je nešto važno, barem se tako prezentira i vjerujem da je... «(2.4.)). Na kraju rasprave isti stručnjak naglasio je zadovoljstvo sudjelovanjem u fokusnoj grupi jer smatra da je dobio više informacija o tome kao i utjehu jer nije usamljen u svojim nedoumicama i nerazumijevanju.

Zatim su tu nejasnoće vezane uz obiteljsku medijaciju i posredovanje. Stručnjaci obje fokusne grupe smatraju da medijacija nije isto što i posredovanje. Jedna grupa smatra da je medijacija puno šira, ima veće mogućnosti, zahtijeva veće vremensko razdoblje za rad i da ponekad uključuje dobrovoljne korisnike koji znaju da će se oni trebati međusobno dogovarati. Navode da se posredovanjem normalizira trenutna situacija, i da je za navedeni postupak zakonodavac jasno propisao kako bi trebao izgledati (za razliku od medijacije), pri čemu postoji pravilnik i jasna je fokusiranost na partnerske odnose. (»Ja bi se tu samo složila s kolegicom jer medijacija je puno šira od posredovanja, posredovanjem pokušavamo normalizirati trenutnu situaciju koliko više možemo i pronaći nekakve smjernice za dalje. Kod medijacije imamo i puno veći vremenski rok i puno više mogućnosti.« (1.1.);»...jasne su stvari koje mi trebamo dobiti, koje informacije trebamo dobiti, kako ćemo mi do njih doći to sad ovisi o nama... "(1.1.)). Naime, Obiteljski zakon (NN, 116/03.) propisuje postupak posredovanja, a Pravilnikom o osnovnim elementima koje mora sadržavati stručno mišljenje u postupku posredovanja prije razvoda braka (NN, 32/05.) definirano je kako mora izgledati stručno mišljenje koje posredovatelj donosi na kraju procesa, dok se obiteljska medijacija spominje tek u Zakonu o socijalnoj skrbi iz 2011. (NN, 57/11.) koji nije dao tako detaljne smjernice za provedbu. Također, stručnjaci ovdje ne dovode u pitanje opravdanost stručnog mišljenja koje zahtijeva procjenu i analizu. Druga grupa sudionika posredovanje doživljava presloženo i mnogo šire u odnosu na medijaciju (»Ja mislim da medijacija i posredovanje nije isto. Medijacija je zasebno za sebe dio nekakvih postupaka, posredovanjem dobivamo presloženu situaciju. Znači, mi možemo medijaciju, posredovanje provoditi samo da dovedemo roditelje do odluke da se usuglase s kim će djeca živjeti, da ih se negdje dovede do odluka 
najboljih za dijete, samo u tom dijelu. Ovo je suviše komplicirano samo posredovanje po sebi. ... Posredovanje je puno više, puno složenije nego što je medijacija.«(2.6.)). I ovo je djelomično razumljivo jer je dosadašnje posredovanje obuhvaćalo pravne i psihosocijalne edukacije o posljedicama razvoda braka uz dogovor roditelja ili procjenu kao temelj stručnog mišljenja. Sveukupno, vidljiva je zbunjenost oko cilja medijacije, odnosno posredovanja pri čemu se stručnjaci teško odvajaju od zakonske svrhe posredovanja (prevladavanje bračnih nesuglasica), dok istovremeno smatraju kako je cilj medijacije sporazum. Kako riječ mirenje u kontekstu razvoda ima ponajprije značenje nastavka partnerske veze, valja naglasiti da cilj obiteljske medijacije nije pomirenje sudionika, odnosno neovisno o pomirenju, potrebno je dogovoriti se i surađivati oko roditeljskih ili drugih obiteljskih pitanja ne samo u izradi sporazuma već i na praktičnoj dnevnoj osnovi. Ukoliko postoji ambivalencija oko prekida partnerske veze i želja za prevladavanjem nesuglasica, potrebno je ući u postupak partnerskog savjetovanja ili terapije.

Analiza je ukazala i na nejasnoće vezane uz savjetovanje i medijaciju. Stručnjaci percipiraju razliku između savjetovanja i medijacije, smatrajući da pri razvodu braka provode savjetovanje, a ne medijaciju i zapravo propituju gdje je granica. Smatraju da je riječ o sličnim postupcima, ali da savjetovanje podrazumijeva hitno i rano interveniranje te stjecanje uvida, da je preopćenito i nema faze, a medijacija je više strukturirana i pretpostavlja suprotstavljene strane (»U razvodima brakova, $i$ provodi se zapravo neki oblik savjetovanja, ja to ne bi nazvala medijacijom, jer većina nas i nije prošla formalnu obuku za medijatore. Ali u procesu savjetovanja, kad nam se, recimo, nama se znaju javiti bračni supružnici da imaju problema, pa ih pozovemo, pa im ponudimo savjetodavnu pomoć i onda radimo nešto što bi se moglo zvati medijacija. Ja to zovem savjetodavni rad, kao usluge savjetovanja. Kao pomoć u prevladavanju poteškoća." (1.1.) s čime se slaže (1.5.): ».. a možda da postoji taj vremenski period koji bi mogli imati na raspolaganju bi se radilo o medijaciji i onda bi se to moglo koristiti.» (1.4.); kod medijacije »...moraš imati korake koji te budu negdje doveli. Dok kod savjetovanja je to previše, preopćenito. ... ali medijacija podrazumijeva strukturiranost i neke faze koje savjetovanje nema. Pa je savjetovanje usmjereno na prve, rane intervencije, da se problem riješi do kraja." (1.6.); »Mi možemo staviti, npr. kako će se nositi roditelji s djetetom koje ima poteškoće ili invalidnost. To je onda savjetovanje. Nekako čim imamo suprotstavljene strane već to prelazi granicu savjetovanja."(1.3.)). Pozitivno je to što zaključuju da savjetovanje nije toliko strukturirano i usmjereno je na stjecanje uvida za razliku od medijacije.

Navedene nejasnoće ukazuju na zbunjenost stručnih radnika oko razumijevanja i poznavanja obiteljske medijacije kao profesionalnog postupka, no to nije neobično s obzirom na needuciranost stručnjaka iz područja obiteljske medijacije i brojne neusklađenosti s kojima se hrvatsko zakonodavstvo, ali i stručna praksa u ovom području suočavaju.

\section{6 članci}


M. Breber , B. Sladović Franz: Uvođenje obiteljske medijacije u sustav socijalne skrbi...

\section{Dosadašnja iskustava u provedbi posredovanje prilikom razvoda braka i u centrima za socijalnu skrb i medijacije u drugim obiteljskim pitanjima}

Drugo istraživačko pitanje bilo je usmjereno na upoznavanje $s$ iskustvima stručnjaka u području predmeta istraživanja. Ovo tematsko područje rezultiralo je specifičnim temama koje se odnose na situacije u kojima se obiteljska medijacija provodi, očekivanjima koja su prisutna tijekom provedbe procesa, okolnostima koje olakšavaju provedbu te preprekama (tablica 2.).

Tablica 2. Dosadašnja iskustava u provedbi posredovanja prilikom razvoda braka i medijacije u drugim obiteljskim pitanjima

\section{Tematsko područje:}

Dosadašnja iskustva stručnjaka u provedbi posredovanja prilikom razvoda braka i medijacije u drugim obiteljskim pitanjima

\begin{tabular}{l|l}
\hline Tema & Kategorija \\
\hline Situacije primjene & $\begin{array}{l}\text { Razvod braka } \\
\text { Razni obiteljski sukobi }\end{array}$ \\
\hline Očekivanja tijekom provedbe & $\begin{array}{l}\text { Stručnjačka } \\
\text { Korisnička }\end{array}$ \\
\hline \multirow{2}{*}{ Okolnosti koje olakšavaju provedbu } & $\begin{array}{l}\text { Aktivno sudjelovanje sukobljenih strana i } \\
\text { stručnjaka } \\
\text { Razumijevanje cjelokupnog procesa } \\
\text { Isti ili slični pogledi na ciljeve i problem } \\
\text { Protok vremena - odmak od akutnog su- } \\
\text { koba } \\
\text { Samostalnost u odluci }\end{array}$ \\
\hline \multirow{2}{*}{ Prepreke } & $\begin{array}{l}\text { Uvjeti i organizacija rada } \\
\text { Obilježja korisnika } \\
\text { Obilježja stručnjaka } \\
\text { Svrhovitost postupka kod sporazumnih } \\
\text { razvoda braka } \\
\text { Podnošenje tužbe za razvod prije postup- } \\
\text { ka posredovanja. } \\
\text { Dvostruka uloga centra } \\
\text { Suradne organizacije i institucije }\end{array}$ \\
\hline
\end{tabular}




\section{a) Situacije primjene}

Stručnjaci navode da se posredovanje provodi u situacijama vezanim uz razvod braka gdje navode zakonom propisane situacije sukladno članku 44. Obiteljskog zakona (NN, 116/03.) kada je riječ o partnerima s maloljetnom djecom i u slučaju tužbe za razvod braka (»Kad se jedan ne želi razvesti, a drugi želi.« (1.3.); »Prvo i prvo u postupku posredovanja jer to je zakonska obveza da svi koji imaju maloljetnu djecu su dužni proći postupak posredovanja.« (2.2.)). No, ujedno spominju i druge razne obiteljske sukobe, kao što su situacije nakon razvoda braka kada se pojave problemi vezani uz skrb djeteta (»Provodi se i nakon postupka razvoda braka, kad su problemi oko susreta i druženja, kad se roditelji nikako ne mogu dogovoriti i navlače to dijete.«(2.3.)). i problemi roditelja i djece ( „... između roditelja i djece, ako se trebaju, ne znam, dogovoriti o vremenu izlaska ...tu se radi o adolescentima." (2.7.)). Navedeno pokazuje da neovisno o tome što to nije eksplicitno u zakonu navedeno, stručnjaci u praksi rade s članovima obitelji unutar drugih socijalnih usluga koje pružaju.

\section{b) Očekivanja tijekom provedbe medijacijskog procesa}

Sudionici fokusnih grupa razlikuju stručnjačka očekivanja od korisničkih. Stručnjaci od korisnika očekuju proradu i ventiliranje emocija, osvještavanje osobnih pogrešaka, stjecanje uvida, pa i očuvanje bračne zajednice, čime dodatno potvrđuju usmjerenost na promjenu odnosa ( "Da prorade te neke svoje situacije, neovisno o tome kakav bude ishod... da si osvijeste to što im se sad dešava,... da proventiliraju to svoje stanje, da vide gdje su sada, da osvijeste te neke pogreške koje su ih do toga dovele, pa da ne ponavljaju to u drugim odnosima... "(1.6.); da govore o tome "što oni vide da ih je dovelo da su spremni na razvod braka. Što bi voljeli promijeniti jedni kod drugog, kod sebe, u braku, obitelji, da bi bili zadovoljniji, sretniji, da bi se ta bračna zajednica ipak održala.«(2.4)). Stručnjaci ujedno očekuju racionalnu procjenu situacije i definiranje željenih promjena što je na tragu druge faze Hollierovog četverofaznog modela medijacije (1993., prema Sladović Franz, 2005.) gdje se kreira mapa sukoba, odnosno, osim što se identificira glavni sadržaj sukoba, definiraju se stvarne želje i potrebe korisnika. Općenito se može zaključiti da su očekivanja stručnjaka prema korisnicima u skladu sa stručnjačkom percepcijom uspješne medijacije. Kod korisničkih očekivanja stručnjaci procjenjuju da su korisnici općenito nerealni pri čemu ne očekuju osobni angažman u rješavanju problema, već ga traže od stručnjaka. Drugim riječima, očekuju instant rješenja od djelatnika centra za socijalnu skrb, da se cijela situacija što prije završi te da će im se pružiti prilika za ocrnjivanje partnera (»Mislim da oni dolaze s očekivanjima da ćemo mi riješiti njihove probleme, i da imamo instant rješenja, ne očekuju da ćemo mi od njih tražiti da sami daju prijedloge i onda se iznenade.«(1.3.)).

\section{8 članci}


Kako bi se izbjegla ovakva očekivanja od korisnika, tijekom procesa važno je na samom početku upoznati korisnike s načinom rada, ulogama i svim relevantnim pitanjima u svezi postupaka koji prethode razvodu ili rješavanju drugih spornih obiteljskih pitanja te je stoga planirano obvezno savjetovanje u prijedlogu novog Obiteljskog zakona značajan doprinos tome. Također, svaki obiteljski medijator prije uključivanja sudionika u medijaciju dužan je provesti predmedijacijski postupak upravo kako bi se pojasnila pravila i odgovornosti svih sudionika obiteljske medijacije i omogućilo dobrovoljno informirano sudjelovanje i preuzimanje odgovornosti.

\section{c) Okolnosti koje olakšavaju provedbu}

Kao okolnost koja pridonosi provedbi obiteljske medijacije stručnjaci percipiraju aktivno sudjelovanje sukobljenih strana i stručnjaka (»Sudjelovanje svih strana, i stručnjaka i korisnika." (1.2.); »Motivacija." (1.5.)). Drugim riječima, kontekst sukoba mora biti važan za korisnike kako bi imali želju za radom na njegovom rješavanju što potvrđuju Camplair i Stolberg (1990., prema Irving i Benjamin, 1995.) u svojem istraživanju te još dodaju volju za kompromisom kao drugi važan aspekt koji pridonosi postizanju sporazuma. Može se zaključiti da stručnjaci prepoznaju jedan od ključnih uvjeta za uspješnu provedbu medijacije, spremnost i motivaciju korisnika, gdje u raspravi ističu i potrebu preuzimanja odgovornosti za vlastite odluke. Zatim naglašavaju važnost razumijevanja cjelokupnog procesa (»...objasni što se tu radi, što se očekuje, nekakvi ciljevi koje trebamo postići, da se uopće razumijemo zašto smo na tom mjestu i što trebamo napraviti. I onda kad je svima jasno, i jednoj idrugoj strani, da se onda krene posredovati... (1.4.)). Na neki način percipiraju svrhu strukturiranosti medijacije u smislu jasnog definiranja pravila i uloga u procesu te očekivanja i ciljeva korisnika. Nadalje, proces olakšavaju isti ili slični pogledi na ciljeve i problem od strane sudionika sukoba (»Ako imaju jednake ciljeve postavljene u glavi, ako od prilike slično vide problem onda i često bude učinkovito.« (2.7.); „Gledaju dobrobit djeteta i pokušavaju se angažirati oboje." (2.2.)). Za očekivati je da, ukoliko strane u sukobu kao prioritete postavljaju iste ili slične stvari, lakše će doći do sporazuma. Ujedno smatraju da je potreban protok vremena - odmak od akutnog sukoba kako bi se olakšalo pregovaranje, što je u skladu s preporukama za neprovođenje obiteljske medijacije u ranim fazama prekida (Parkinson, 2011.). Jedan sudionik posebno naglašava mogućnost pregovaranja nakon proteka određenog vremena kao presudnu okolnost za uspješni dogovor jer smatra da u situaciji intenzivnih emocija korisnici ne mogu donijeti racionalne odluke i sporazume 
(»....mislim da stvarno treba jedan protek vremena. Jer kad su stvari friške, da ih savjetujete ne znam koliko, ne možete postići što ipak može neki protek vremena. Kad se malo ohlade, kad malo promisle, kad neke stvari sjednu na mjesto ... a nakon nekog proteka vremena stvari sjednu na svoje mjesto. ...Ali kad malo prođe vrijeme, ipak krenu neki dogovori.«(1.2.)). Samostalnost u odluci jednako je tako važna okolnost koja olakšava i pridonosi uspjehu medijacije (»... da to bude baš njihov dogovor. Jer je najveća vjerojatnost da će ga tako poštovati. Da je to nešto što će oni dalje slijediti. I vezano za djecu i za sve dalje vezano za njihov odnos koji moraju imati nakon razvoda braka." (2.1.)). Značajno je da stručnjaci prepoznaju važnost mogućnosti samoodređenja pri donošenju sporazuma jer je upravo jedna od temeljnih načela i vrijednosti obiteljske medijacije da odluke donose članovi obitelji koji s njima moraju živjeti te na taj način zadržavaju dignitet i kontrolu.

\section{d) Prepreke}

Brojne su poteškoće i prepreke koje stručnjaci prepoznaju u provedbi posredovanja prilikom razvoda braka i medijacije u drugim obiteljskim pitanjima. Jedna od bazičnih poteškoća odnosi se na uvjete i organizaciju rada što je vidljivo kroz neadekvatne prostorne i tehničke uvjete, preopterećenost količinom posla stručnih radnika centra u smislu velikog broja korisnika, malo vremena i premalo stručnog kadra. Također, stručnjaci navode problem »brojanja predmeta« na kraju godine iz čega se može zaključiti da je sustav ocjenjivanja i vrednovanja rada stručnjaka nelogičan i utječe na kvalitetu rada. Problem je i u radnom vremenu koje često ne odgovara korisnicima, pa se teško zakazuju susreti. Zatim su prepoznate i prepreke vezane uz život i rad u maloj sredini, riječ je o situaciji koja bitno otežava rad stručnih radnika jer korisnici dovode u pitanje njihove prosudbe i odluke s obzirom na isprepletenost uloga, a ponekad se javlja i problem geografske udaljenost i prometne (ne)povezanosti korisnika s lokalnim centrima (»...nekad je i ljudima teško dolaziti ujutro i onda dolazi do poteškoća u terminima. Pa se ne možemo naći dva mjeseca jer ili radi na terenu ili radi stalno ujutro pa ne može dobiti slobodan dan ili tako..." (1.1.); »Povećani broj korisnika, mali broj kadrova, neadekvatni uvjeti rada, prostorni $i$ sve ostalo." (2.2.); "Ja bi još jednu poteškoću navela ...tu se radi o maloj sredini gdje se svi ljudi međusobno poznaju i susreću u koje kakvim raznoraznim ulogama unutar redovnog posla i van... i to nekad čini poteškoću oko sumnje u objektivno donošenje nekakvih odluka, kad nisu stranke, korisnici naši suglasni. Pa onda nas upletu u kojekakve situacije koje nisu nimalo ugodne, gdje se na sudu nađete u takvoj situaciji da se govori da ste donijeli potpuno subjektivno odluku na temelju priča rekla-kazala. lako u mišljenjima navodimo konkretno dokaze koje smo koristili, pisana izvješća, testiranja sve što je potrebno u kojem slučaju.«(1.4.)).

\section{0 članci}


Obilježja korisnika predstavljaju prepreku u smislu komunikacijskih kapaciteta pri čemu teško razlučuju teme razgovora, konkretno partnerske poteškoće od roditeljskih, te često ponavljaju već rečeno. Također nisu spremni verbalizirati problem, ponekad viču ili pak šute, nastoje ocrniti drugog roditelja te žele pridobiti naklonost stručnog radnika kod odluka o roditeljskoj skrbi. Ujedno dolaze jer moraju, odnosno po sili zakona, i nisu zainteresirani. Zatim su tu prepreke vezane uz uplitanje drugih članova obitelji, prisutnost nasilja u obitelji te patologije i psihičkih bolesti koje dodatno otežavaju rad i provedbu posredovanja prilikom razvoda braka („Stvar je u tome da je ponekad ljudima stvarno teško razlučiti kad ćemo o partnerskim problemima razgovarati, a onda ćemo o djeci.« (1.5.), s čime se slaže i (1.1.): "Ljudi dođu zato jer moraju, na to ih obvezuje zakon ako imaju maloljetnu djecu ili ako je razvod pokrenut tužbom." (2.4.);»Ne znam da li je gore kad se deru i svađaju ili kad samo šute. ... A onda kad oni ne žele ništa reći, mi tu nemamo na temelju čega uopće raditi dalje." (2.4.); »... Jer upravo zbog njegovog lošeg psihičkog stanja ili obojanosti cjelokupne percepcije realnosti njegovom bolešću to komplicira, i zapravo bojkotira i onemogućuje bilo kakvu i medijaciju. "(2.4)). Paquin (1990., prema Irving i Benjamin, 1995.) u svom istraživanju također navodi da su komunikacijske vještine korisnika koje uključuju sposobnost pregovaranja, korištenja »ja« poruka i slično, obilježja koja pridonose sklapanju sporazuma, odnosno njihov izostanak ga otežava. Johnson naglašava i utjecaj obitelji te intenzitet sukoba kao prepreku u donošenju zajedničkih dogovora (1985., prema Irving i Benjamin, 1995.).

Prepreke vezane uz obilježja stručnjaka odnose se na nedostatak interesa stručnih radnika da se bave obiteljskom medijacijom, da stručnjaci koji ju provode nisu adekvatno educirani te su najčešće emocionalno preopterećeni, frustrirani i nakon nekog vremena teško »vide« korisnike (»/sto tako, ako pitate bilo kojeg kolegu da li želi ići raditi u tim za brak i obitelj, nitko neće raditi." (1.2.), što potvrđuju (1.1.), (1.3.), (1.4.), (1.5.) i (1.6.): »Jer je to nešto što je iscrpljujuće... jer smo ono kao kante koje se pune, a niko nas ne prazni. I to je problem. « (1.6.); »Meni kao stručnjaku fali formalni dio edukacije iz medijacije, fali mi struktura medijacije kao takve. Što, kad, kako..." (1.1.)). Sudionici stoga prepoznaju da je osim korisničkih obilježja važan i interes te kompetencija stručnjaka kako bi proces medijacije bio kvalitetan i tekao prema postizanju optimalnih rješenja. Svrhovitost postupka kod sporazumnih razvoda braka neki sudionici vide kao prepreku u smislu gubitka vremena, odrađivanja forme i tehničkog "prolaza« kroz pravilnik. Ipak jedan dio sudionika ne slaže se s time, već smatra da je i kod sporazumnog razvoda braka potrebno provesti medijaciju (»... Ali ako su oni došli sporazumnim prijedlogom i u svemu su u dogovoru i onda dođu k nama na posredovanje, onda je to stvarno odrađivanje forme i gubljenje našega vremena. Ja vidim taj problem. "(1.5.); »Ja se ne bi možda složila s tim... to je potrebno jer je to jedna vrlo važna životna odluka, koja u tom času možda, opet ovisi 
o bračnom paru koji dolazi, može biti ishitrena ili nemamo pojma od kud dolazi taj sporazumni zahtjev i što je sve prethodilo tome... «(1.4.)). Čini se da postoji potreba nekih stručnjaka za uvidom u obiteljsku situaciju u vrijeme razvoda kako bi provjerili način postizanja sporazuma i eventualno ugrožavanje dobrobiti djece, a to će biti moguće upravo kroz planirano obvezno savjetovanje, ali i kroz ovjeru sporazuma od strane suda (prijedlog novog Obiteljskog zakona). Obiteljsku medijaciju ne treba provoditi ako već postoji sporazum o svim bitnim pitanjima. Moguće je koristiti medijacijsku tehniku, motivirajući razgovor i druge pomažuće intervencije unutar postupka obiteljskog savjetovanja kako bi se potaknula i olakšala izrada sporazuma (npr. Plan o zajedničkoj roditeljskoj skrbi) kod roditelja koji su se u većini stvari samostalno dogovorili čime se pružaju informacije i pomoć (npr. oko razumijevanja pravnih, praktičnih ili razvojnih posljedica) uz osiguravanje prava na samoodređenje i neuplitanje u obiteljska pitanja.

Valja naglasiti da problematiku sudjelovanja djeteta u postupku razvoda braka uopće ne spominju u ni jednom kontekstu. Moloney i Mclntosh ${ }^{7}$ govore o dvije vrste medijacijske prakse kada su u pitanju djeca. Riječ je o praksi usmjerenoj na pitanja djece (eng. child focused) gdje stručnjaci informiraju roditelje o utjecajima i posljedicama razvoda braka na djecu, te medijaciji u kojoj djeca aktivno sudjeluju (eng. child inclusive) pri čemu se medijator susreće s djetetom i direktno ga uključuje u za njega važna pitanja istovremeno dajući odgovarajuću povratnu informaciju roditeljima. Iz navedenog je vidljivo, a kao što i sami autori naglašavaju, da je inkluzivna praksa prihvatljivija i u većoj mjeri kompatibilna s Konvencijom o pravima djeteta (2001.), no kod nas do sada nije primjenjivana.

Postupak koji podrazumijeva podnošenje tužbe za razvod prije postupka posredovanja stručnjaci doživljavaju kao prepreku iz razloga što su tada već odnosi partnera teško poremećeni, a motivacija korisnika za prevladavanje krize niska te u konačnici dolazi do većeg broja razvoda (»Pa gledajte... od kako se razvod braka pokreće na sudu, ljudi dolaze u centar, a da su njihovi odnosi tako teško poremećeni, da vrlo malo je spremno na ulaganja radi prevladavanja bračne krize. Već su čvrste odluke da će se razvesti. Ranijih godina to nije bilo tako, ranijih godina je postupak posredovanja prethodio tužbi sudu i tu smo dosta imali različitih situacija, naročito supruge su se obraćale da poplaše malo svoje muževe i u velikom broju slučajeva su ljudi onda bili spremni na ulaganje, nekako ranije su dolazili u centar zbog problematike. Sada dolaze, barem ono što sam ja vidjela i kako dugo radim, od kada se pokreće taj postupak na sudu, veliki broj završava razvodom, ranije je manje završavalo razvodom i ljudi su više ulagali i mnogi su uspjeli prevladati tu bračnu krizu

${ }^{7}$ http://jfs.e-contentmanagement.com/archives/vol/10/issue/1/article/77/childfocused-and-childinclusivemediation, 06.03.2012.

\section{2 članci}


naročito ako su bili spremni na bračno savjetovanje.« (2.2.)). Stručnjaci u raspravi naglašavaju kako je prethodno uređenje postupka posredovanja koje je prethodilo sudskom postupku bilo kvalitetnije rješenje. $S$ jedne strane, medijacija pri razvodu braka zamišljena je za partnere koji su donijeli konačnu odluku, ali izjave sudionika upućuju na preventivnu ulogu obiteljske medijacije koja ne zahvaća samo pitanja vezana uz razvod. Drugim riječima, da su korisnici imali mogućnost, bez obveze obraćanja sudu, rješavanja partnerskih i drugih obiteljskih konflikata koji prethode razvodu braka, možda do takve oduke ne bi došlo. Ukoliko je intenzitet konflikta visok, medijacija će biti znatno teža s obzirom da su tada sudionici sukoba međusobno nepovjerljivi i ljuti (Kressel, 2000.).

Dvostruka uloga centra, odnosno stručnjaka predstavlja veliku prepreku u radu. Stručnjaci ističu kako istovremeno moraju savjetovati korisnika o različitim problematikama, davati stručna mišljenja te štititi i »goniti« korisnike pri čemu gube stečeno povjerenje i mogućnost napretka (»Inače je centar u toj jednoj ulozi da savjetuje, štiti, ali i goni. To je oduvijek bilo tako... Oduvijek smo i kazneno gonili, da se taj drugi osjećao jako loše jer podržavamo ovog drugog i tako u toj dvostrukoj ulozi, ulozi pomagača, ali i ulozi progonitelja.« (2.2.)). U raspravi je vidljivo da višestruke i često međusobno isključujuće uloge centra zbunjuju same stručne radnike, ali i korisnike. Osjećaju se loše kada postupak koji rezultira pozitivnim pomacima moraju prekinuti zbog saznanja određenih informacija kao i kada sugovornicima direktno kažu ( »...nemojte mi reći ... ako mi kažete nešto, ja to moram prijaviti. Tog časa ono malo povjerenja, onaj proces kojim smo došli do toga se razbije.»(2.6.)).

Suradne organizacije i institucije predstavljaju prepreku u vidu česte nemogućnosti daljnjeg upućivanja korisnika specijaliziranim ustanovama dok organizacije koje su dostupne ne uvažavaju mišljenja i preporuke stručnjaka iz centra (»A ne možeš ga nikamo uputiti, možeš ga moliti da se negdje obrati ... možeš obavijestiti doktoricu, koja će poduzeti nešto ili neće, najčešće neće. Ako i pridobijemo ljude da odu kod psihologa, ako uputimo ljude jer dobijemo na psihološkoj obradi da oni nisu dobro psihički. Taj isti psihijatar na kraju nas proglasi ludima jer smo ga uputili tamo jer on to kroz jedan razgovor nije uspio dobiti. A to što smo mi pratili situaciju duže nam ne daje relevantnost, tako da od drugih stručnjaka naših suradnih službi zapravo ispadamo budale i pred tim našim korisnicima s kojima moramo dalje raditi.. (2.4.)). Sudionici također opisuju značaj dobre suradnje koju prvenstveno ostvaruju s nevladinim organizacijama (»... ali s obiteljskim centrom, za sad nismo baš bili zadovoljni. Jer nisu nam davali povratne informacije, oni su to držali nešto za sebe. Za razliku od Djece prve gdje smo u svakom trenutku mogli dobiti što se događa s našim korisnikom, imali smo jedan suradnički odnos. I moglo se to pismeno zatražiti i oni bi to dostavili.«(2.2.)).

Iz navedenog je vidljivo kako su navedene prepreke međusobno povezane i isprepletene, kao da jedna producira drugu. Tako, primjerice, loši uvjeti i organiza- 
cija rada utječu na stručnjake koji su iscrpljeni i frustrirani; neusklađenost zakonske regulative, prije svega sa suvremenim pristupima vezanim uz obiteljsku medijaciju, rezultira nizom prepreka u implementaciji medijacije od informiranosti i obrazovanja stručnjaka do organizacije i provedbe postupka. Stoga i definirane poteškoće ukazuju na temeljne postavke vezane uz obiteljsku medijacije, kao što su edukacija i supervizija stručnjaka, dobrovoljnost sudjelovanja korisnika u procesu, proceduralna fleksibilnost te rješavanja konkretnih, praktičnih sukoba i sporova u različitim organizacijskim okruženjima.

\section{ZAKLJUČNA RAZMATRANJA}

Postoji značajno metodološko ograničenje ovog istraživanja koje se odnosi na prigodni uzorak sudionika, činjenicu da neki od njih imaju vrlo kratko radno iskustvo značajno za temu istraživanja te da je provedeno samo u sjevernom dijelu Hrvatske. Također, zadovoljeni su samo neki od kriterija vrednovanja kvalitativnih istraživanja (Miles i Huberman, 1994., prema Urbanc i Ajduković, 2010.) i to relativna objektivnost (teorijska pozicija i kritički stav), zahtjev za korisnost, primjenjivost i akcijska usmjerenost istraživanja (u smislu povezivanja i pojašnjavanja novih postupaka i zakonskih prijedloga), unutarnja vjerodostojnost (rezultati predočeni višekratno stručnoj javnosti), dok su vanjska valjanost i pouzdanost i provjerljivost podataka samo djelomični. Ipak, temeljem dobivenih rezultata, mogu se uočiti i pojasniti određene slabe točke kao prilog boljem razumijevanju obiteljske medijacije prilikom uvođenja promjena u sustav rješavanja obiteljskih sukoba i obiteljskopravnih sporova.

U prvom redu valja naglasiti razliku između obiteljske medijacije i posredovanja prilikom razvoda braka kako je do sada egzistiralo u hrvatskoj praksi. Osnovne karakteristike obiteljske medijacije su da je visoko strukturirana, usmjerena na rješavanje određenog problema, kratkotrajna i primjenjiva na većinu područja obiteljskih sukoba. Ne ulazi u dubinu odnosa i ne bavi se ispitivanjem uzroka, usmjerena je na sadašnjost i budućnost, a krajnji cilj joj je donošenje sporazuma optimalnog i održivog za sve sudionike sukoba. Posredovanje prije razvoda braka imalo je za cilj edukaciju o posljedicama razvoda, otkrivanje uzroka razvoda braka, pokušaj pomirenja supružnika, pokušaj sporazumnog dogovora o posljedicama razvoda i stručnu procjenu koji su temelj za izradu stručnog mišljenja. Navedeno nikako nije u skladu s načelima obiteljske medijacije, a prije svega s ključnim načelima povjerljivosti, neutralnosti i nepristranosti medijatora. Navedenim su uloge stručnjaka bile višestruko izmiješane što je pridonosilo neuspjehu samog postup-

\section{4 članci}


ka i percepciji korisnika o postupku koji je nekoristan (Očko, 2012.). Dakle, dosadašnje posredovanje nije u skladu s teorijom obiteljske medijacije jer ima za svrhu zapravo neku vrstu savjetodavnog rada s korisnicima i prevladavanje bračnih sukoba, odnosno (po)mirenje partnera, a ne postizanje sporazuma. lako je obiteljska medijacija usmjerena na rješavanje konkretnih sukoba te nije usmjerena na prošlost i osobnu promjenu sudionika, promjenu nečije osobnosti, osobni su uvidi i promjene mogući kao i prilikom svake pomažuće intervencije kojom se osnažuje pojedinca i podržava u preuzimanju kontrole nad vlastitim životom. Stoga, ako se tijekom obiteljske medijacije potakne ili prepozna ambivalencija prema odlukama i pojavi mogućnost održavanja braka, sudionike valja potaknuti na partnersko ili individualno savjetovanje ili terapiju.

Navedeno je povezano s činjenicom da se do sada u razvodu braka propustio iskoristiti preventivni učinak koji obiteljska medijacija može imati ukoliko se primjenjuje na vrijeme i za različite obiteljske sukobe, s obzirom na činjenicu da je razvod braka samo jedan od mogućih obiteljskih sporova i najčešće eskalacija i posljedica brojnih prethodnih neriješenih sukoba. Naime, socijalni rad općenito bavi se socijalnim problemima koji egzistiraju na individualnoj, obiteljskoj i društvenoj razini te između ostalog proizlaze iz različitih sukoba. Krajnja svrha socijalnog rada je poboljšanje kvalitete života kroz jačanje kapaciteta pojedinca, obitelji i zajednica te može kontinuirano predstavljati podršku u rješavanju sukoba koji se, posebno kod razvoda braka, nastavljaju i dalje, te učiti i poticati korisnike na miroljubive pregovore u svrhu osnaživanja i dobrobiti svih članova obitelji. Jedno od rijetkih istraživanja u ovom području koje su provele Trgovčević i Sladović (1997.) još prije petnaest godina, pokazuje kako sami socijalni radnici uviđaju potrebu za medijacijom i to u situacijama obiteljskih sukoba, prije svega supružnika, zatim roditelja i djece, prilikom razvoda, ali i između kolega na radnom mjestu. Upotrebu medijacije kao vještine i pojedinih medijacijskih tehnika unutar drugog profesionalnog postupka (npr. unutar bračnog savjetovanja, prilikom provođenja mjera obiteljsko pravne zaštite djece, itd.) svakako treba poticati, ali i razlikovati od provođenja cjelovitog i zasebnog postupka obiteljske medijacije.

Nadalje, iskustva iz prakse pokazuju da je postupak posredovanja u praksi usmjeren isključivo na statusna pitanja i u pravilu se ne odnosi na imovinska pitanja koja su neizbježan dio razvoda braka. Sporazumnim rješavanjem svih spornih pitanja u postupku obiteljske medijacije treba izbjeći ponavljanje postupaka, ali i prebacivanje sadržaja sukoba iz jednog područja u drugo, a najčešće iz imovinskih u roditeljska (Sladović Franz, 2005.). Stoga unutar obiteljske medijacije, neovisno o tome provodi li se unutar ili izvan sustava socijalne skrbi, treba osigurati pravni savjet i pomoć kako bi sudionici odlučivali na temelju relevatnih pravnih činjenica i bili u stanju donijeti prikladne sporazume kako o roditeljskim tako i o imovinskim 
pitanjima te svim drugim obiteljskim pravima i obvezama (kao npr. obveze uzdržavanja, pravo na viđanje unuka, itd.).

Dobiveni podaci ukazuju na veliko nerazumijevanje obiteljske medijacije od strane stručnjaka, posebice u odnosu na razlike s drugim profesionalnim postupcima, osobito bračnim savjetovanjem što nije rijedak slučaj (Corey, 2004.), dok istovremeno uspijevaju definirati obiteljsku medijaciju kao strukturiran proces koji se vodi oko sukoba sa svrhom donošenja sporazuma na obostrano zadovoljstvo.

Zasebno je pitanje nalaz da korisnici imaju prevelika i nerealna očekivanja od stručnjaka koji bi trebali riješiti njihove probleme. Istraživanje perspektive korisnika posredovanja prilikom razvoda braka pokazalo je štoviše da korisnici ovaj postupak »pronalaze uglavnom negativnim; nejasnim, besmislenim, obvezujućim te nepotrebno prolongiranim« (Očko, 2012.: 23), ali i da prenošenje odgovornosti za postizanje dogovora na njih same doživljavaju kao kršenje etičkih načela i pravila struke od strane stručnjaka. Navedeno upućuje na nužnost pravovremenog i valjanog informiranja korisnika kako bi mogli odabrati usluge koje na najbolji način zadovljavaju i štite njihove potrebe i interese.

Prijedlog novog Obiteljskog zakona u ovom je području usmjerio sve sudionike - članove obitelji, stručnjake socijalne skrbi i suce prema sporazumnom rješavanju sukoba i sporova jer razvod ili druga pitanja o djeci sami po sebi nisu pitanje socijalne skrbi niti pravosuđa niti je potrebna intervencija osim ako su ugrožena nečija prava i interesi. Obiteljska je medijacija samo jedan od načina koji pridonosi tom cilju. Kao preduvjet zajedničke roditeljske skrbi postavlja se obaveza donošenja Plana o zajedničkoj roditeljskoj skrbi pod pretpostavkom da sposobnost dogovaranja o svim pitanjima vezanima za dijete ujedno ukazuje i na sposobnost provedbe jer sporazumni dogovori povećavaju motivaciju, razdvajaju roditeljsku od partnerske uloge te smanjuju neprijateljstvo i potencijalnu manipulaciju djecom. Procjena prepostavki za ulazak u obiteljsku medijaciju jedan je od vrlo specifičnih profesionalnih zadataka nužnih u ovom prodručju zbog zaštite ranjivijih članova obitelji koji zbog osobnih obilježja, prethodnih obiteljskih iskustava i dugotrajnih složenih obiteljskih emotivnih odnosa mogu obiteljskom medijacijom biti u dodatnom riziku od obiteljskog nasilja te ne biti u mogućnosti u potpunosti, slobodno i pravilno zastupati svoje interese (Parkinson, 2011.). Stoga je predmedijacijski postupak koji se provodi prilikom prvog susreta s obiteljskim medijatorom (koji se planira kao obavezan prema prijedlogu novog Obiteljskog zakona) uobičajeni i nužan standard obiteljske medijacije, nakon kojeg se može, ako su ispunjene pretpostavke i ako to sudionici dobrovoljno žele, odmah nastaviti s medijacijskim postupkom ili dati sudionicima vrijeme potrebno za promišljanje o adekvatnosti obiteljske medijacije te se može u postupak ući naknadno kada se ostvare pretpostavke.

\section{6 članci}


M. Breber , B. Sladović Franz: Uvođenje obiteljske medijacije u sustav socijalne skrbi...

Uvijek treba imati na umu da obiteljska medijacija, jednako kao i druge socijalne usluge i pomažuće intervencije, mora odgovarati na potrebe korisnika. Ukoliko se želi uspostaviti kvalitetan sustav obiteljske medijacije, potrebno je integrirati suvremene teorijske postavke s preporukama i iskustvima drugih zemalja i međunarodnih organizacija, ali i prijedlozima korisnika i domaćih stručnjaka koji se svakodnevno susreću s obiteljskim pitanjima, ne samo iz sustava socijalne skrbi već i iz pravosuđa, vjerskih zajednica i udruga civilnog društva. Svaki od navedenih aktera ima specifičnu značajnu ulogu u razvoju i poticanju sporazumnih načina rješavanja obiteljskih sukoba i sporova i priliku razvijanja različitih organizacijskih pristupa obiteljskoj medijaciji kako bi korisnici imali priliku birati modele obiteljske medijacije prema sadržaju spora i obiteljskim obilježjima.

LITERATURA

1. Ajduković, M. (2012). Vještine interpersonalne komunikacije. U: Žižak, A., Vizek Vidović, V. \& Ajduković, M. (ur.), Interpersonalna komunikacija u profesionalnom kontekstu. Zagreb: Edukacijsko-rehabilitacijski fakultet, 93-146.

2. Ajduković, M. \& Sladović Franz, B. (2003). Razumijevanje sukoba. U: Ajduković, D. (ur.), Socijalna rekonstrukcija zajednice. Zagreb: Društvo za psihološku pomoć, 195-210.

3. Ajduković, M. \& Urbanc, K. (2010). Kvalitativna analiza iskustva stručnih djelatnika kao doprinos evaluaciji procesa uvođenja novog modela rada u centre za socijalnu skrb. Ljetopis socijalnog rada, 17 (3), 319-352.

4. Alinčić, M. (1999). Europsko viđenje postupka obiteljskog posredovanja. Revija za socijalnu politiku, 6 (3-4), 227-240.

5. Breber, M. (2012). Mišljenje stručnjaka centara za socijalnu skrb o obiteljskom medijaciji. Završni specijalistički rad. Studijski centar socijalnog rada, Pravni fakultet u Zagrebu.

6. Corey, G. (2004). Terapija obiteljskih sistema. U: Corey, G. (ur.), Teorija i praksa psihološkog savjetovanja i psihoterapije. Jastrebarsko: Naklada Slap, 387-437.

7. Filipović, G. \& Osmak-Franjić, D. (2010). Manipulacija djecom tijekom razvoda braka ili prekida izvanbračne zajednice roditelja - iz perspektive pravobraniteljice za djecu. Djeca i konfliktni razvodi. Zagreb: Ured pravobraniteljice za djecu.

8. Irving, H. H. \& Benjamin, M. (1995). Research in Family Mediation: An Integrative Review. In: Irving, H. H. \& Benjamin, M. (eds.), Family mediation: Contemporary issues. California: Sage Publications, Inc., 407-424. 
9. Koller-Trbović, N. \& Žižak, A. (2008). Kvalitativni pristup u društvenim znanostima. Zagreb: Edukacijsko-rehabilitacijski fakultet.

10. Korać, A. (2005). Obiteljsko posredovanje - prilog alternativnom rješavanju obiteljskih sporova. Hrvatska pravna revija, 5, 73-84.

11. Kressel, K. (2000). Mediation. In: Deutsch, M. \& Coleman, P. T. (eds.), The handbook of conflict ressolution: Theory and practice. San Francisco: Jossey Bass, 522-545.

12. Kruk, E. (1997). Mediation and conflict resolution in social work and the human services: Issues, debates, and trends. In: Kruk, E. (ed.), Mediation and conflict resolution in social work and the human services. Chicago: Nelson-Hall, Inc., 1-17.

13. Majstorović, I. (2007). Posredovanje prije razvoda braka: Hrvatsko pravo i europska rješenja. Zbornik Pravnog fakulteta u Zagrebu, 57 (2), 405-456.

14. Milas, G. (2005). Istraživačke metode u psihologiji i drugim društvenim znanostima. Jastrebarsko: Naklada Slap.

15. Milne, A., Folberg, J. \& Salem, P. (2004.) The evolution of divorce and family mediation: An overview. In: Folberg, J., Milne, A. \& Salem, P. (eds.), Divorce and family mediation: Models, techniques and applications. New York: The Guilford Press, 3-25.

16. Moloney, L. \& McIntosh, J. E. (2004.) Child-focused and Child-inclusive mediation: A comparative study of outcomes. Preuzeto s: http:// jfs.e-contentmanagement.com/archives/vol/10/issue/1/article/77/ childfocused-and-childinclusive-mediation (06.03.2012.).

17. Obiteljski zakon, Narodne novine, 116/03, 17/04, 136/04, 107/07, 57/11, 61/11, 25/13.

18. Očko, N. (2011). Upotreba medijacije u tri europske države: Uređenje postupka obiteljske medijacije. Završni specijalistički rad. Studijski centar socijalnog rada, Pravni fakultet u Zagrebu.

19. Očko, N. (2012). Korisnička perspektiva postupka posredovanja prije razvoda braka. Diplomski rad. Studijski centar socijalnog rada, Pravni fakultet u Zagrebu.

20. Parkinson, L. (2011). Family mediation: Appropriate dispute resolution in a new family justice system. London: Family Law.

21. Pravilnik o osnovnim elementima koje mora sadržavati stručno mišljenje u postupku posredovanja prije razvoda braka, Narodne novine, br. 32/05.

22. Sladović Franz, B. (2005). Obilježja obiteljske medijacije. Ljetopis Studijskog centra socijalnog rada, 12, 2, 301-319.

23. Sladović Franz, B. (2010). Medijacija i socijalni rad. Radni materijal.

24. Srivastava, A. \& Thomson, S. B. (2009). Framework analysis: A qualitative methodology for applied policy research. JOAAG, 4, 2 
M. Breber , B. Sladović Franz: Uvođenje obiteljske medijacije u sustav socijalne skrbi...

25. Tkalac Verčič, A., Sinčić Ćorić, D. \& Pološki Vokić, N. (2010). Priručnik za metodologiju istraživačkog rada. Zagreb: M.E.P. d.o.o.

26. Trgovčević, N. \& Sladović, B. (1997). Potrebe i interesi za posredovanjem u socijalnom radu. Ljetopis Studijskog centra socijalnog rada, 4, 119-129.

27. Urbanc, K. \& Ajduković, M. (2010). Novi model rada centara za socijalnu skrb: Izazovi i preporuke. Ljetopis socijalnog rada, 17 (3), 353-389.

28. Uzelac, A. (2004). Mirenje kao alternativa suđenju. U: Uzelac, A. \& sur., Mirenje u građanskim, trgovačkim i radnim sporovima. Zagreb: TIM press, 15-28.

29. Uzelac, A., Aras, S., Maršić, M., Mitrović, M., Kauzlarić, Ž. \& Stojčević, P. (2010). Aktualni trendovi mirnog rješavanja sporova u Hrvatskoj: Dosezi i ograničenja. Zbornik Pravnog fakulteta u Zagrebu, 60 (3), 1265-1308.

30. Zakon o mirenju (2011). Narodne novine, 18/11.

31. Zakon o socijalnoj skrbi (2011). Narodne novine, 57/11.

32. Zakon o socijalnoj skrbi (2012). Narodne novine, 33/12.

33. Zakon o socijalnoj skrbi (2013). Narodne novine, 157/13.

34. Žižak, A. (2012). Teorije o komunikaciji i komunikacijske tradicije. U: Žižak, A., Vizek Vidović, V. \& Ajduković, M. (ur.), Interpersonalna komunikacija u profesionalnom kontekstu. Zagreb: Sveučilište u Zagrebu. Edukacijskorehabilitacijski fakultet, 55-74.

\section{MREŽNI IZVORI}

1. European Code of Conduct for Mediators (2004). Preuzeto 25.10.2011. na mrežnoj stranici: http://ec.europa.eu/civiljustice/adr/adr_ec_code_ conduct_en.pdf.

2. Green paper on alternative dispute resolution in civil and commercial law COM (2002) 196 final. Preuzeto 24.11.2011. na mrežnoj stranici: http:// eurlex.europa.eu/ LexUriServ/ site/en/com/ 2002/com20020 196en01.pdf.

3. Preporuka Vijeća ministara br. R (98) 1 o obiteljskom posredovanju. Preuzeto s: http://www. prevodi.gov.me/ Ostalo/31998H0001.pdf. https://wcd.coe. int/ViewDoc.jsp?id=461347\&Site=COE\&BackColorInternet=DBDCF2\&Back ColorIntranet=FDC864\&BackColorLogged=FDC864 (21.07.2011.).

4. Prijedlog novog Obiteljskog zakona. Preuzeto s: www.mspm.hr. 
Ljetopis socijalnog rada 2014., 21 (1), 123-152 str.

Marija Breber

Branka Sladović Franz

Department of Social Work,

Faculty of Law

University of Zagreb

\section{INTRODUCING FAMILY MEDIATION IN SOCIAL CARE SYSTEM - PROFESSIONALS' PERSPECTIVES}

\section{SUMMARY}

It is argued that, the experiences in divorce proceedings mediation and the knowledge of social care expert opinions regarding family mediation are some of the preconditions needed for the implementation of family mediation services within the social care system. This paper aims to demonstrate the current family mediation system characteristics in order to improve collective understanding and development of family mediation services. The research used a qualitative approach to collect data from the discussions of the two focus groups. The two groups consisted of 13 experts (psychologists and social work professionals). Furthermore, a thematic analysis method was applied for all data processing. The research findings point to the experts who are familiar with the basic knowledge about mediation processes. On the other hand, findings show that amongst the experts there is a degree of confusion regarding mediation process. The confusion is especially evident in relation with other professional procedures and when the aims of family mediation questions are raised. Furthermore, the results show that $t$ the conflict reduction, better communication, gaining insight and reaching agreements are positive mediation outcomes.

Based on the past experiences, the research shows that in addition to the divorce mediation experts also use mediation in post- divorce and parent- child conflicts. Furthermore, the research describes the barriers which are technical or organisational by nature but also the ones that are users and experts specific. The insights gained during the research are commented on in the conclusion. Subsequently, to conclude one aims to illuminate the weak points within the current mediation procedures and to treat the advancement of the same as the prerequisite for achieving coherent family mediation concepts and better future legislative and organisational solutions.

Key words: family mediation, divorce mediation, helping profession experts perspectives. 